\title{
Converting ToD Vehicle from Gasoline to LPG in Indonesia: Cost Identification and Investment Analysis
}

\author{
Muhammad Imron Rosyidi ${ }^{1}$, Eko Muh Widodo $^{1}$, Tuessi Ari Purnomo ${ }^{1}$, Muji Setiyo ${ }^{2 *}$, \\ Djoko Wahyu Karmiadji ${ }^{3}$
}

\begin{abstract}
${ }^{1}$ Department of Industrial Engineering, Universitas Muhammadiyah Magelang, Magelang, 56172, Indonesia ${ }^{2}$ Department of Automotive Engineering, Universitas Muhammadiyah Magelang, Magelang, 56172, Indonesia ${ }^{3}$ Agency for the Assessment and Application of Technology, Tangerang Selatan, 15314, Indonesia
\end{abstract}

\begin{abstract}
The increasing number of transportation on demand (ToD) or online fleets in Indonesia, as well as the rise in gasoline prices, is a concern for most online fleet drivers. However, there is an opportunity to convert online fleets from gasoline to Liquefied Petroleum Gas (LPG) because LPG for vehicles is available in several big cities in Indonesia at a relatively low price compared to gasoline RON 90. Therefore, we present a feasibility simulation study for converting online fleets from gasoline RON 90 to LPG using two scenarios, with and without annual vehicle tax and inspection costs as scenario 1 and scenario 2, respectively. Simulation results with operational data suggest that investment is feasible today. The net present value (NPV), internal rate of return (IRR), and payback period (PP) show promising values. The NPV was IDR 35.52 and 41.14 million with an IRR of 7\% and 8\% for scenario 1 and scenario 2, respectively. The PP was obtained at 14 and 13 months for scenario 1 and scenario 2, respectively. However, this investment appears to be risky if there is a decrease in daily mileage and an increase in LPG prices simultaneously.
\end{abstract}

Keywords: Converting to LPG; Feasibility analysis; Online fleet

\section{Introduction}

In North America and Europe, the phenomenon of transportation on demand (ToD) or online fleets as well as car-sharing has been around for a long time, and was reported more than 70 years ago (Shaheen and Cohen, 2012; Cuevas et al., 2016). In the past 10 years, carsharing has spread to five continents. Recently, the phenomenon of car-sharing has influenced people to delay buying a new car (Hui et al., 2019). In Indonesia, ToD was pioneered in 2010 by GO-JEK but only began to grow substantially in 2015. Initially, GO-JEK was present in Jakarta as a motorcycle transportation service and expanded widely, and then competed with GrabTaxi. The rivalry between GO-JEK with GrabTaxi intensified when Uber entered the market in 2014. By 2016, competition among the three companies (GOJEK, GrabTaxi, and Uber) was fierce. GrabTaxi changed its name to Grab and compete with GO-JEK especially Go-Car, but UBER stopped operating.

The presence of ToD such as Grab and Go-Car in urban areas has affected mobility patterns. The benefits and risks of the presence of ToD have been discussed in detail from various perspectives, including economic, social, and policy (Natadjaja and Setyawan, 2016; 
Wahyuningtyas, 2016; Nurhidayah and Alkarim, 2017; Silalahi et al., 2017; Azzuhri and Mada, 2018). ToD is a new solution for consumers, when conventional transportation services are unreliable, such as uncertainty schedule and altered routes due to congestion (Arifin and Axhausen, 2012). ToD is available anytime in almost all major cities in Indonesia.

For example, Figure 1 shows ToD availability in three cities in Indonesia at midnight, when city buses does not operate.

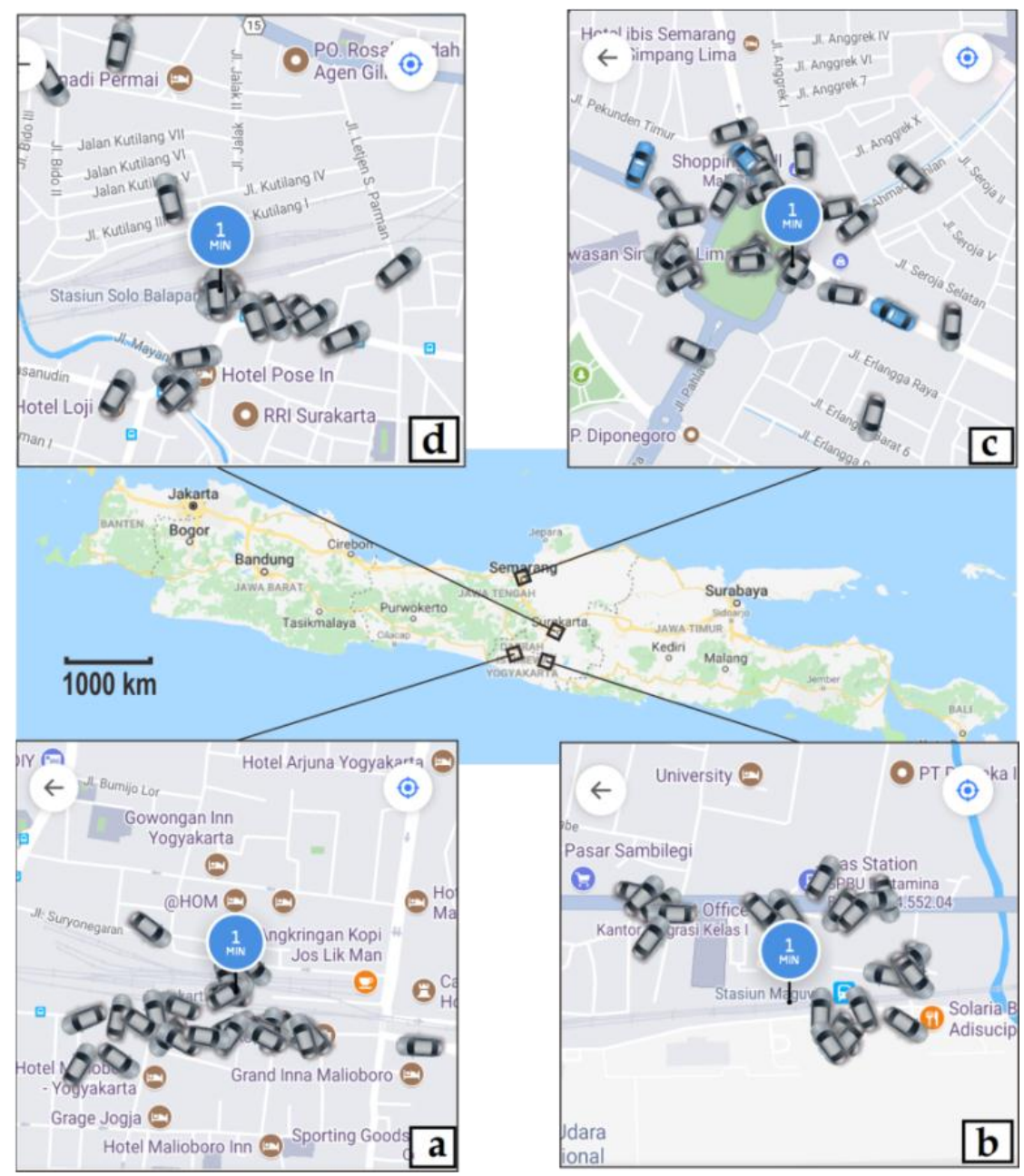

Figure 1 Online Fleet Availability In Several Cities In Central Java, Indonesia: (a) Yogyakarta Train Station; (b) Yogyakarta Airport; (c) Semarang Intersection; and (d) Solo Train Station

In early 2016, thousands of conventional fleet drivers demonstrated because their income declined due to the presence of ToD. This incident appeared in all mass and electronic media in Indonesia. Demonstrators demanded that vehicles used by Uber, Grab, and Go-Car be tested and inspected by the Department of Transportation as under the regulations for taxis and other public fleets. Demonstrators also demanded that ToD be owned by a legal entity or cooperative to limit the number of the fleet. By the end of 2016, some conventional taxies that had previously opposed ToD changed their policy. Some now saw online transportation services as an opportunity, and some joined existing ToD fleets. Until the beginning of 2018, precise data about the number of online fleets operating was not available. However, the Ministry of Transportation provided a quota of 91,953 online fleet units operating in all cities in Indonesia (CNBC Indonesia, 2018). 
As a result, due to the huge number of vehicles, since the end of 2016, GO-JEK and Grab have come under pressure from their drivers because their incomes have declined by $50 \%$. Therefore, the registration of new drivers is limited to maintaining supply and demand (Kusuma, 2018). We validated this data by surveying ToD drivers in Yogyakarta. They experienced a decrease in income with the increase in vehicles, especially those who worked as full-time drivers. This phenomenon worsens when the government limits the supply of subsidized fuel, which is gasoline RON 88 (Premium) sold by the government for IDR 6,550. ToD drivers must purchase non-subsidized fuel such as gasoline RON 90 and RON 92 at a higher price. At the time of writing, the price of gasoline RON 90 was IDR 7,800 and RON 92 was IDR 8,900, 19\% and 36\% higher than RON 88, respectively. On the other hand, there is the potential to replace gasoline with LPG, which has a better environmental impact and lower prices than gasoline, around IDR 5100 per liter equivalent to premium. In 2018, WLPGA reported at least 136 types of LPG-fueled vehicles produced as Original Equipment Manufacturer (OEM) (WLPGA, 2018). However, the practice of replacing an existing fleet with a new fleet is not easy to implement (Deendarlianto et al., 2017). As an alternative, adding LPG converter kits to the existing fleet is a reasonable solution so that vehicles can operate with LPG.

We chose LPG because it is available at fuel stations in many major cities in Indonesia (12 in Jakarta and its surroundings, 3 in Surabaya, 3 in Denpasar, and 1 in Bandung, Semarang, Yogyakarta, and Magelang, respectively). The cost of converting from conventional fuel to LPG is also lower than to Compressed Natural Gas (CNG) due to the lower LPG pressure compared to CNG, so the conversion equipment is cheaper. In addition, LPG has been shown to produce lower emissions and has a high octane number that can be applied to high-compression spark-ignition engines to get the best performance. The loss of power in LPG engines can be increased by various methods to approach gasoline engine power (Kaleli et al., 2015; Çinar et al., 2016; Suyabodha, 2017). Based on the description of the problems related to online fleet driver competition, fuel prices, and the benefits of LPG as an alternative fuel, we present a techno-economic simulation of the use of LPG for ToD.

\section{Methods}

\subsection{Cost Identification}

Several types of costs must be considered by vehicle owners or the government before converting private vehicles or public fleets to LPG. Liu et al. (1997) identified the costs of conversion as capital cost, maintenance cost, and fuel cost. However, their report did not specify the components of the three main costs. Recently, a study reported a calculator for assessing the investment feasibility of converting gasoline to LPG, but the calculator did not include the annual tax and inspection cost (Widodo et al., 2019).

Other costs must be included in the calculation to make the right investment decision. Based on the experience of countries that successfully promoted LPG as a substitute for gasoline, the government plays a role, for example, by enacting tax exemptions and requiring annual inspections (Leung, 2011; Raslavičius et al., 2014). Under the terms of the conversion provided by the Propane Education and Research Council (2011a, 2011b), not all vehicles that come to the conversion facility can be served immediately. Technical requirements must be met for the car to be converted, including a complete inspection of the engine mechanics for oil leaks, compression pressure, noise, and emissions. If the technical requirements are not met, the vehicle owner must incur additional costs before conversion for engine standardization. The amount is unpredictable, depending on the condition of the vehicle to be converted. Therefore, a conversion cost model is presented in Figure 2. The costs for operating fleets with gasoline include fuel costs, maintenance costs, 
and vehicle tax charges. To operate fleets with LPG, there are additional conversion costs before fuel costs, maintenance costs, and vehicle tax charges.

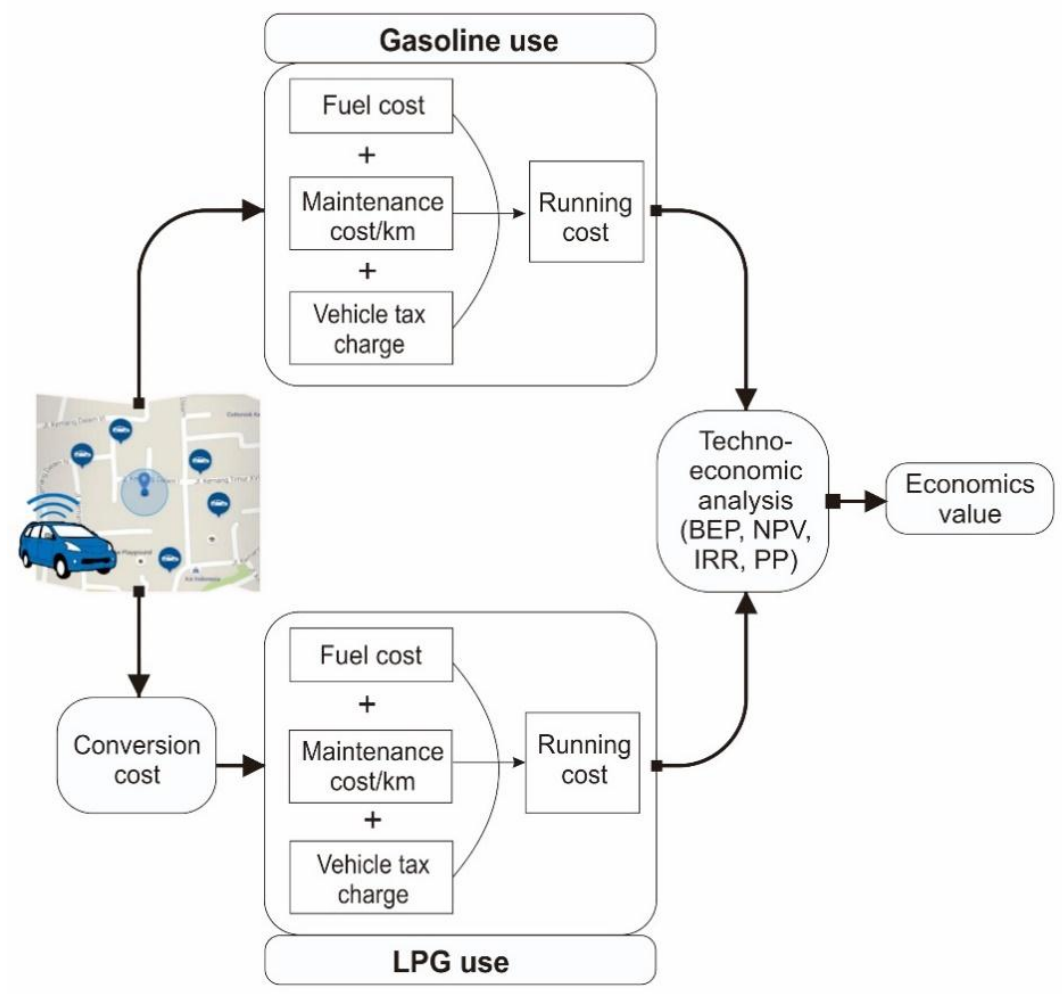

Figure 2 Cost parameter for converting a gasoline-powered vehicle to LPG

\subsection{Investment Feasibility}

In this study, the investment feasibility of converting an online fleet from gasoline to LPG includes three main parameters that are commonly used to assess investment feasibility, namely Net Present Value (NPV), internal Rate of return (IRR), and Payback Period (PP) (Arshad, 2012; Žižlavský, 2014). The cash inflows (Ci) used in the calculation are the average gross income of ToD drivers per month, and the cash outflows $(\mathrm{Co})$ are the average operation costs per month. The NPV is calculated using Equation 1 as follows:

$$
N P V=\left(C i_{0}-C o_{i}\right)+\frac{\left(C i_{1}-C o_{1}\right)}{(1+i)}+\frac{\left(C i_{2}-C o_{2}\right)}{(1+i)^{2}}+\cdots+\frac{\left(C i_{n}-C o_{n}\right)}{(1+i)^{n}}+\frac{S}{(1+i)^{n}}-I_{0}
$$

If the net benefit ( $\mathrm{Ci}-\mathrm{Co}$ ) and interest $(i)$ are assumed to remain unchanged during $n$ period, and the salvage values are 0 , Equation 1 can be rewritten as Equation 2 . Then, the IRR is a condition where the NPV is equal to 0 :

$$
N P V=\left[\frac{(C i-C o) x\left[1-(1+i)^{-n}\right]}{i}\right]-I_{0} .
$$

After the NPV and the IRR are known, the investment is assessed by calculating the payback period. The payback period is the ratio of the capital costs with accumulative proceeds as shown in Equation 3:

$$
P P=\frac{\text { investment costs }}{\text { accumulative proceeds }}
$$




\section{Results and Discussion}

Based on Figure 2, the values for the parameters used in the online fleet simulation in which vehicles were converted from gasoline RON 90 to LPG operate for $200 \mathrm{~km}$ per day are presented in Table 1.

Table 1 Operational costs of online fleet using gasoline RON 90 vs. LPG

\begin{tabular}{|c|c|c|c|}
\hline Parameters & Unit & $\begin{array}{l}\text { Gasoline } \\
\text { RON } 90\end{array}$ & LPG \\
\hline Mileage per year $(\mathrm{Vm})$ & $\mathrm{km}$ & 57,600 & 57,600 \\
\hline Fuel consumption $(F C)$ & $\mathrm{km} / \mathrm{l}$ & 12 & 12 \\
\hline Annual fuel consumption $\left(F c_{a n}\right)$ & liter & 4,800 & 4,800 \\
\hline Fuel price/litre, ( $C_{g}$ for gasoline and $C_{g}$ for LPG) & IDR & 7,800 & 5,100 \\
\hline Annual fuel cost $\left(C_{g, a n}\right.$ for gasoline and $C_{L, a n}$ for LPG) & IDR & $\begin{array}{r}37,440,00 \\
0\end{array}$ & $24,480,000$ \\
\hline Cost of LPG kits $\left(C_{c k}\right)$ & IDR & - & $10,000,000$ \\
\hline Cost of engine standardization $\left(C_{e s}\right)$ & IDR & - & $5,000,000$ \\
\hline $\begin{array}{l}\text { Oil maintenance cost per kilometer }\left(C_{o g, k m} \text { for gasoline and } C_{o L, k m}\right. \\
\text { for LPG) }\end{array}$ & IDR & 32 & 23 \\
\hline $\begin{array}{l}\text { Oil maintenance cost per year }\left(C_{o g} \text {, an for gasoline and } C_{o L, \text { an }} \text { for }\right. \\
\text { LPG) }\end{array}$ & IDR & $1,843,200$ & $1,316,571$ \\
\hline Spare part and washing cost per year $\left(C_{s p, a n}\right)$ & IDR & $6,650,000$ & $6,650,000$ \\
\hline Annual vehicle tax, inspection, and membership cost $\left(C_{v a, a n}\right)$ & IDR & $1,500,000$ & $1,500,000$ \\
\hline Running cost $/ \mathrm{km}$ for gasoline $\left(C_{r c, g}\right)$ & IDR & 823 & - \\
\hline Running cost $/ \mathrm{km}$ for LPG with tax and inspection cost $\left(C_{r c, L}\right)$ & IDR & - & 589 \\
\hline Running cost/km for LPG without tax and inspection cost $\left(C_{r c, L}\right)$ & IDR & - & 563 \\
\hline $\begin{array}{l}\text { BEP LPG to gasoline RON } 90 \text { with tax and inspection cost } \\
\text { (scenario 1) }\left(C_{r c, L}\right)\end{array}$ & $\mathrm{km}$ & - & 64,063 \\
\hline $\begin{array}{l}\text { BEP LPG to gasoline RON } 90 \text { without tax and inspection cost } \\
\text { (scenario 2) }\left(C_{r c, L}\right)\end{array}$ & $\mathrm{km}$ & - & 57,651 \\
\hline
\end{tabular}

The values of the parameters given in column 3 and column 4 in Table 1 are explained as follows: capital costs, $C_{c}=C_{c k}+C_{e s}$; annual fuel consumption, $F c_{a n}=\frac{V m}{F c}$; annual fuel cost for gasoline, $C_{g, a n}=F c_{a n} x C_{g}$; annual fuel cost for LPG, $C_{L, a n}=F c_{a n} x C_{L}$; and annual maintenance cost for gasoline, $C_{m g, a n}=C_{o g, a n}+C_{s p, a n}$; annual maintenance cost for LPG, $C_{m L, a n}=C_{o L, a n}+C_{s p, a n}$; and annual vehicle administration costs, $C_{v a, a n}=C_{t a x, a n}+C_{i n s, a n}$. Next, running cost $/ \mathrm{km}$ for gasoline and LPG was calculated as $C_{r c, g}=\frac{C_{g}}{F_{c}}+\frac{\left(C_{m g, a n}+C_{v a, a n}\right)}{V m}$ and $C_{r c, L}=$ $\frac{C_{L}}{F_{c}}+\frac{\left(C_{m L, a n}+C_{v a, a n}\right)}{V m}$, repectively. Finally, Break Even Point (BEP) distance LPG to gasoline was calculate as $B E P_{D}=\frac{C_{c}}{\left(C_{r c, g}-C_{r c, L}\right)}$.

\subsection{Break Even Point}

Table 1 shows that the operation cost for vehicles with gasoline RON 90 is IDR 832/km. The cost with LPG is IDR 589/ km and IDR $563 / \mathrm{km}$ with and without tax and inspection costs, respectively. When online fleet owners convert their vehicles to LPG, there is a cost of IDR 15,000,000 to buy the LPG kits and to standardize the engines. At the initial investment, car owners do not immediately see a benefit; they must wait until the difference in running costs (proceeds) reaches the cost of capital to benefit from the conversion 
program, as presented in Figure 3. The BEP can be pursued more closely if the government exempts taxes and inspection costs for the online fleet with LPG.

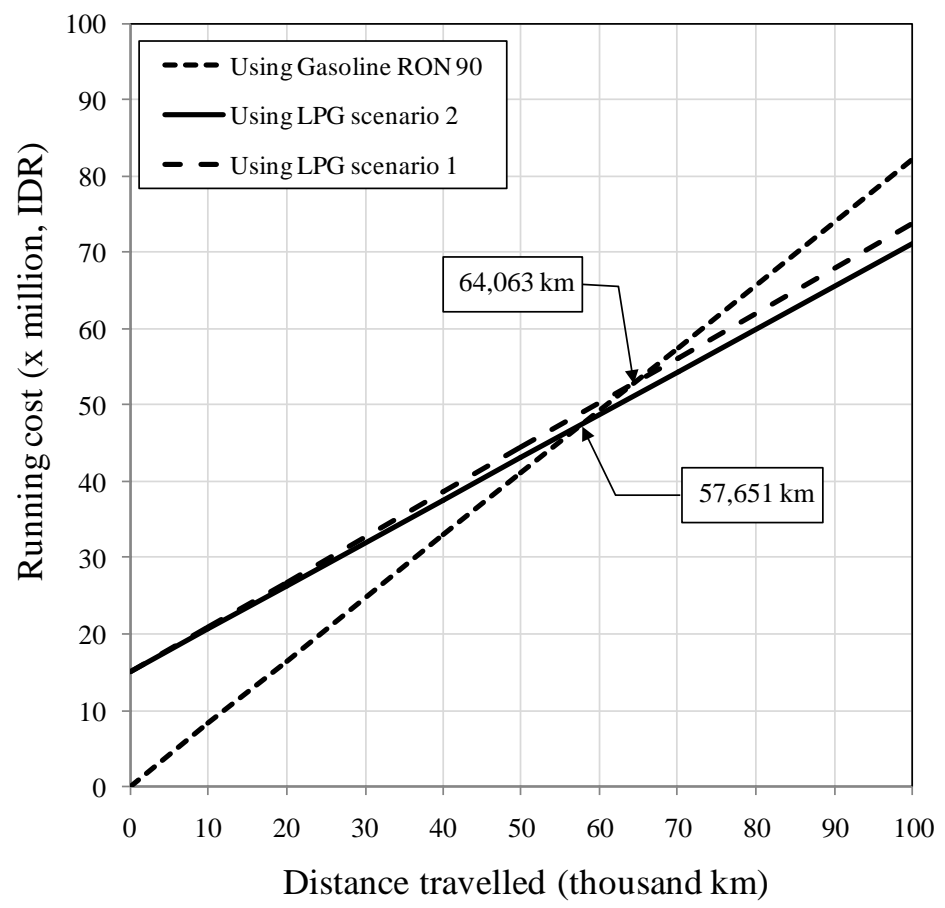

Figure 3 Break Even Point for converting online fleet to LPG

\subsection{The Net Present Value and the Internal Rate of Return}

The NPV is the most important parameter in considering conversion to LPG; online fleet owners can directly compare the value of the investment. Assuming the lifetime of LPG kits is 60 months, and the bank interest rate is $1 \%$ per month, an initial investment of IDR 15,000,000 and a running cost difference of IDR 234/km and IDR 260/km for scenarios 1 and 2, the NPV can be calculated with Equation 2. We use the interest rate of 1\% per month based on the rate issued by Bank Indonesia during January to October 2018. The highest rate for investment loans was $11.58 \%$ per year (regional government banks). Meanwhile, the general interest rate was $10.33 \%$, averaged from state banks, regional government banks, national private banks, foreign banks and mixed banks, and commercial banks (Bank Indonesia, 2018).

The NPV simulation results are presented in Figure 4, where the NPV is IDR 35.52 and 41.14 million for scenario 1 and scenario 2, respectively. An NPV value greater than 0 indicates that this investment is feasible to implement. Next, the IRR can be simulated by increasing the bank interest rate until the NPV equals 0 . The simulation results showed that the IRR for this investment can reach $7 \%$ and $8 \%$ for scenario 1 and scenario 2 , as presented in Figure 5. Investment with an IRR of 7-8\% per month is very attractive because the minimum acceptable rate of return (MARR) for all banks in Indonesia is $6.0 \%$ per year or only $0.5 \%$ per month (Bank Indonesia, 2019). With the same capital costs for scenario 1 and scenario 2, which is IDR 15,000,000 as an investment for conversion to LPG, scenario 2 is preferred because it produces a greater NPV and IRR. 


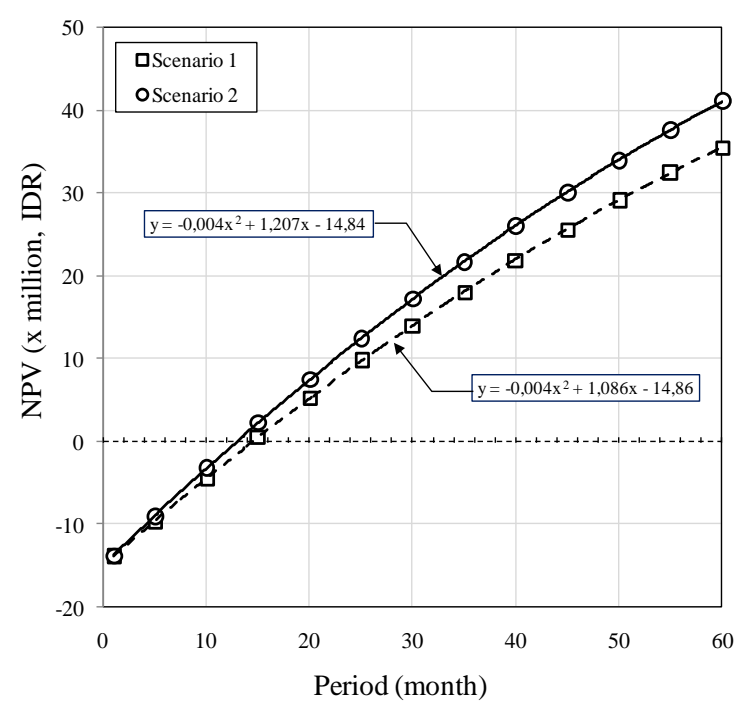

Figure 4 NPV of converting online fleet to LPG

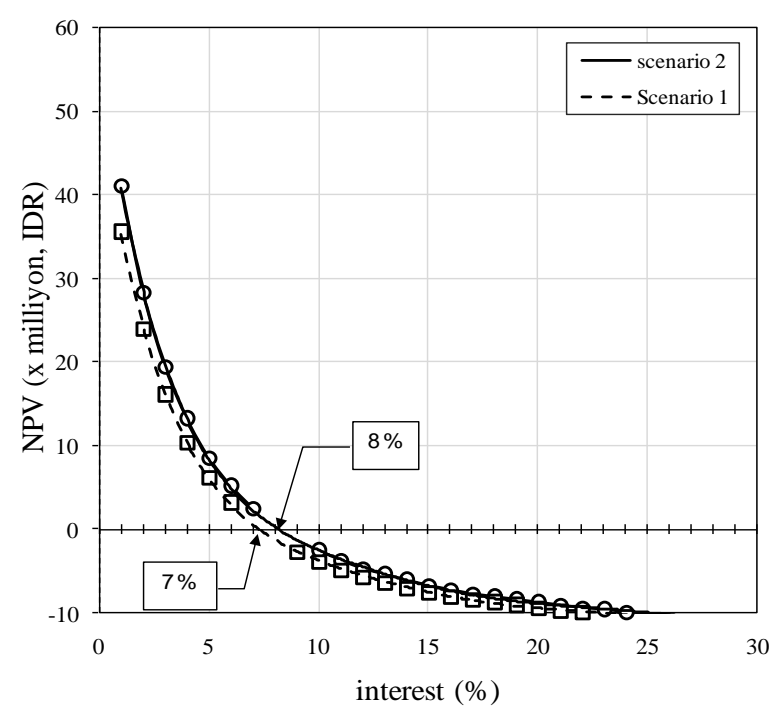

Figure 5 IRR of converting online fleet to LPG

\subsection{Payback Period}

The payback period is the time required to return the investment value that has been issued at the time of gasoline conversion to LPG. The PP is very important in making investment decisions, where the PP is compared with the lifetime of the LPG kits. In this study, we assumed that the lifetime of the LPG kits was equal to the bank installment period, which was 60 months. The PP simulation results are presented in Figure 6, where the PP was obtained at 14 and 13 months for scenario 1 and scenario 2, respectively.

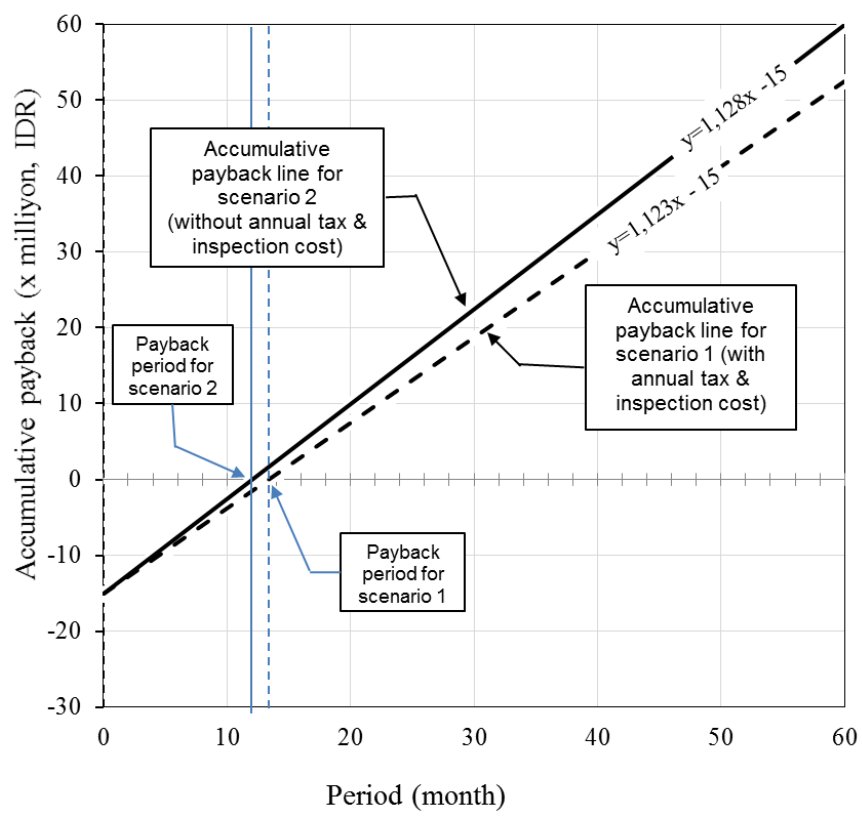

Figure 6 Payback Period of converting online fleet to LPG

The NPV, IRR, and PP calculations showed that LPG is promising as an alternative to conventional gasoline. The use of LPG-fueled fleets is also reported to be increasing in developing countries, such as Turkey, Poland, India, Ukraine, Mexico, and Ghana as a substitute for gasoline for the efficiency and economic benefits, in addition to 
environmental reasons. (Karamangil, 2007; European LPG Association, 2013; Jung and Koo, 2018).

\subsection{Challenges and Opportunities}

Although the NPV, IRR, and PP calculations showed a positive investment feature, the positive values occur only if the input parameters do not change drastically. As in previous studies (Setiyo et al., 2016), NPVs are sensitive to two input parameters, changes in mileage per year and the difference in price between gasoline and LPG per liter. If the price difference of LPG to gasoline remains at IDR 2,700, the NPV will be close to 0 if the mileage per day is $60 \mathrm{~km}(17,280 \mathrm{~km} /$ year $)$. If the driver maintains a daily distance of $200 \mathrm{~km}$ $(57,600 \mathrm{~km} /$ year $)$, the investment is feasible until the price of LPG is IDR 7,000 to gasoline IDR 7,800 (89\%).

There is a possibility that LPG prices will increase and the daily mileage will decrease. If the sensitivity increases to 30\%, where the price of LPG becomes IDR 6,630 and the daily mileage is $140 \mathrm{~km}$, then the NPV is IDR 1.11 and 6.73 million, the IRR is $1.25 \%$ and $3.0 \%$, and the PP is 42 and 32 months for scenario 1 and scenario 2, respectively. Conversely, if the daily mileage is higher, and the price difference between gasoline and LPG increases, then the BEP and the PP will be shorter. Meanwhile, the NPV and the IRR will increase.

Another challenge in implementing LPG for vehicles, including for ToD, is the readiness of facilities and technicians to carry out conversions that meet government standards. LPG is a fuel that changes states easily due to changes in temperature and pressure. Therefore, reliable conversion facilities and technicians are needed for large-scale implementation, including government policies that provide incentives for the procurement of converter kits, workshop certification, and technicians (Biscoff et al., 2012).

\section{Conclusions}

The simulation study showed that investing the conversion of online fleet from gasoline RON 90 to LPG is feasible today. This program will further assist car owners if the government provides waivers or exempts owners from taxes and inspection costs. The government can also promote loans with bank interest rates below 1\% per month or by giving free converter kits to online fleet owners. Additional analysis showed this investment is resistant to daily mileage reduction to less than $100 \mathrm{~km}$ and LPG price increases to $89 \%$ of RON 90 gasoline prices. However, these investments appear to be risky if there is a decrease in daily mileage and an increase in the price of LPG simultaneously.

\section{Acknowledgments}

This article is part of research funded by the Ministry of Research Technology and Higher Education, Republic of Indonesia through the scheme of Penelitian Dasar Unggulan Perguruan Tinggi (PDUPT). The researchers also thank the Center of Research Development and Community Services of the Universitas Muhammadiyah Magelang for their support.

\section{Abbreviations}

$\begin{array}{llll}\text { BEP } & \text { Break Even Point } & \text { NPV } & \text { Net Present Value } \\ \text { IRR } & \text { Internal Rate of Return } & \text { PP } & \text { Payback Period } \\ \text { LPG } & \text { Liquefied Petroleum Gas } & \text { ToD } & \text { Transportation on Demand } \\ \text { MARR } & \text { Minimum Acceptable Rate of Return } & & \end{array}$




\section{Nomenclature}

\begin{tabular}{|c|c|c|c|}
\hline$C_{c}$ & Total of capital cost, IDR & $C_{o L, a n}$ & Annual oil cost for LPG, IDR \\
\hline$C_{c k}$ & Capital Cost for LPG kits, IDR & $C_{r c, g}$ & Running cost / km for gasoline, IDR \\
\hline$C_{e s}$ & $\begin{array}{l}\text { Capital cost for engine standardization, } \\
\text { IDR }\end{array}$ & $C_{r c, L}$ & Running cost/km for LPG, IDR \\
\hline$C_{g}$ & Gasoline price/liter, IDR & $C_{s p, a n}$ & $\begin{array}{l}\text { Annual spare part and washing cost per } \\
\text { year, IDR }\end{array}$ \\
\hline$C_{g, \text { an }}$ & Annual fuel cost for gasoline, IDR & $C_{t a x, \text { an }}$ & Annual vehicle tax, IDR \\
\hline $\mathrm{Ci}$ & Cash inflows, IDR & $C_{v a, a n}$ & $\begin{array}{l}\text { Annual vehicle administration costs, } \\
\text { IDR }\end{array}$ \\
\hline$C_{\text {ins, an }}$ & Annual inspection, IDR & $F C$ & Fuel consumption, km/l \\
\hline$C_{L}$ & LPG price/liter equivalent to gasoline, IDR & $F C_{a n}$ & Annual fuel consumption, liter \\
\hline$C_{L, a n}$ & Annual fuel cost for LPG, IDR & $i$ & Bank interest, \% \\
\hline$C_{m g, a n}$ & Annual maintenance cost for gasoline, IDR & $I_{o}$ & Initial investment, IDR \\
\hline$C_{m L, a n}$ & Annual maintenance cost for LPG, IDR & $n$ & Period, month \\
\hline Co & Cash outflows, IDR & $S$ & Salvage value in the end of period, IDR \\
\hline$C_{o g}$, an & Annual oil cost for gasoline, IDR & $V m$ & Vehicle mileage per year, km/year \\
\hline
\end{tabular}

\section{References}

Arifin, Z.N., Axhausen, K.W., 2012. Investigating Commute Mode and Route Choice Variabilities in Jakarta using Multi-day GPS Data. International Journal of Technology, Volume 3(1), pp. 45-55

Arshad, A., 2012. Net Present Value is better than Internal Rate of Return. Interdisciplinary Journal of Contemporary Research in Business, Volume 4(8), pp. 211-219

Azzuhri, A.A., Mada, U.G., 2018. A Creative, Innovative, and Solutive Transportation for Indonesia with Its Setbacks and How to Tackle Them: A Case Study of the Phenomenal GOJEK. Review of Integrative Business and Economics Research, Volume 7(1), pp. 59-67

Bank Indonesia, 2018. Indonesian Economic and Financial Statistics-November 2018. Jakarta

Bank Indonesia, 2019. Data BI 7-Day Repo Rate - Bank Sentral Republik Indonesia. Available online at https://www.bi.go.id/, Accessed on January 18, 2019

Biscoff, R., Akple, M., Turkson, R., Klomegah, W., 2012. Scenario of the Emerging Shift from Gasoline to LPG Fuelled Cars in Ghana: A Case Study in Ho Municipality, Volta Region. Energy Policy, Volume 44(C), pp. 354-361

Çinar, C., Sahin, S., Can, Ö., Uyumaz. A., 2016. A Comparison of Performance and Exhaust Emissions with Different Valve Lift Profiles Between Gasoline and LPG Fuels in a SI Engine. Applied Thermal Engineering, Volume 107, pp. 1261-1268

CNBC Indonesia, 2018. Dibatasi 91.953 Taksi Online Unit, Ini Kuota Setiap Kota (Online Taxis are Limited to 91,953 units, This is the Quota of Each City). Available Online at https://www.cnbcindonesia.com/, Accessed on January 10, 2019

Cuevas, V., Estrada, M., Salanova, J.M., 2016. Management of On-demand Transport Services in Urban Contexts. Barcelona Case Study. Transportation Research Procedia, Volume 13, pp. 155-165

Deendarlianto, Widyaparaga, A., Sopha, B.M., Budiman, A., Mutohar, I., Setiawan, I.C., Lindasista, A., Soemardjito, J., Oka, K., 2017. Scenarios Analysis of Energy Mix for Road Transportation Sector in Indonesia. Renewable and Sustainable Energy Reviews, Volume 70, pp. 13-23

European LPG Association, 2013. Autogas in Europe, The Sustainable Alternative: An LPG Industry Roadmap. Brussels, Belgium: AEGPL 
Hui, Y., Wang, Y., Sun, Q., Tang, L., 2019. The Impact of Car-sharing on the Willingness to Postpone a Car Purchase: A Case Study in Hangzhou, China. Journal of Advanced Transportation, Volume 2019, pp. 1-11

Jung, J., Koo, Y., 2018. Analyzing the Effects of Car Sharing Services on the Reduction of Greenhouse Gas (GHG) Emissions. Sustainability, Volume 10(2), pp. 1-17

Kaleli, A., Ceviz, M.A., Erenturk, K., 2015. Controlling Spark Timing for Consecutive Cycles to Reduce the Cyclic Variations of SI Engines. Applied Thermal Engineering, Volume 87, pp. 624-632

Karamangil, M.I., 2007. Development of the Auto Gas and LPG-Powered Vehicle Sector in Turkey: A Statistical Case Study of the Sector for Bursa. Energy Policy, Volume 35(1), pp. 640-649

Kusuma, H., 2018. Pendaftaran Sopir Taksi Online Disetop karena Penghasilan Menurun (Online Taxi Driver Registration Stopped because of Declining Income), DetikFinance. Available Online at https://finance.detik.com/, Accessed on January 10, 2019

Leung, V., 2011. Slow Diffusion of LPG Vehicles in China-lessons from Shanghai, Guangzhou and Hong Kong. Energy Policy, Volume 39(6), pp. 3720-3731

Liu, E., Yue, S.Y., Lee, J., 1997. A Study on LPG as a Fuel for Vehicles. Report RP05/96-97, Research and Library Services Division Legislative Council Secretariat, $4^{\text {th }}$ Floor, Central Government Offices (West Wing), 11 Ice House Street, Central, Hong Kong

Natadjaja, L., Setyawan, P.B., 2016. Creating Community through Design: The Case of Go-Jek Online. International Journal of Cultural and Creative Industries, Volume 4(1), pp. 1827

Nurhidayah, F., Alkarim, F., 2017. Domination of Transportation Network Companies (TNCs) in Indonesia: An Indonesian Case. International Journal of Business, Economics and Law, Volume 12(3), pp. 11-20

Propane Education and Research Council, 2011a. Converting Vehicles to Propane Autogas Part 1: Installing Fuel Tanks and Fuel Lines. Washington, D.C.

Propane Education and Research Council, 2011b. Converting Vehicles to Propane Autogas Part 2: Installing Underhood Components. Washington, D.C.

Raslavičius, L., Keršys, A., Mockus, S., Keršiene, N., Starevičius, M., 2014. Liquefied Petroleum Gas (LPG) as a Medium-term Option in the Transition to Sustainable Fuels and Transport. Renewable and Sustainable Energy Reviews, Volume 32, pp. 513-525

Setiyo, M., Soeparman, S., Hamidi, N., Wahyudi, S., 2016. Techno-economic Analysis of Liquid Petroleum Gas Fueled Vehicles as Public Transportation in Indonesia, International Journal of Energy Economics and Policy, Volume 6, pp. 495-500

Shaheen, S.A., Cohen, A.P., 2012. Carsharing and Personal Vehicle Services: Worldwide Market Developments and Emerging Trends. International Journal of Sustainable Transportation, Volume 7(1), pp. 5-34

Silalahi, S.L.B., Handayani, P.W., Munajat, Q., 2017. Service Quality Analysis for Online Transportation Services: Case Study of GO-JEK. Procedia Computer Science, Volume 124, pp. 487-495

Suyabodha, A., 2017. Comparison the Rate of Energy Consumption between Gasoline 95 and LPG in Spark Ignition Engine under Real Driving Conditions. Energy Procedia, Volume 118, pp. 164-171

Wahyuningtyas, S.Y., 2016. The Online Transportation Network in Indonesia: A Pendulum between the Sharing Economy and Ex Ante Regulation. Competition and Regulation in Network Industries, Volume 17(3-4), pp. 260-280 
Widodo, E.M., Rosyidi, M.I., Purnomo, T.A., Setiyo, M., 2019. Converting Vehicle to LPG/Vigas: A Simple Calculator to Assess Project Feasibility. Automotive Experiences, Volume 2(2), pp. 34-40

World LPG Asociation (WLPGA), 2018. Autogas Vehicles Catalogue 2018. Neuilly-sur-Seine: WLPGA

Žižlavský, O., 2014. Net Present Value Approach: Method for Economic Assessment of Innovation Projects. Procedia - Social and Behavioral Sciences, Volume 156, pp. 506512 